\title{
Nitrogen for growth of stock plants and production of strawberry runner tips
}

\author{
Djeimi Isabel Janisch (1*); Jerônimo Luiz Andriolo ('); Vinícius Toso ('); Kamila Gabriele Ferreira dos \\ Santos ( $\left.{ }^{2}\right)$; Jéssica Maronez de Souza $\left({ }^{2}\right)$ \\ (') Universidade Federal de Santa Maria (UFSM), Centro de Ciências Rurais, Programa de Pós-Graduação em Agronomia (PPGA). \\ Avenida Roraima, n. ${ }^{\circ}$ 1000, 97105-900 Santa Maria (RS), Brasil. \\ (2) UFSM, Curso de Graduação em Agronomia, Santa Maria (RS), Brasil. \\ (*) Corresponding author: djeimi_agro@yahoo.com.br
}

Received: Jan. 2, 2012; Accepted: June 10, 2012

\begin{abstract}
The objective of this research was to determine growth and dry matter partitioning among organs of strawberry stock plants under five Nitrogen concentrations in the nutrient solution and its effects on emission and growth of runner tips. The experiment was carried out under greenhouse conditions, from September 2010 to March 2011, in a soilless system with Oso Grande and Camino Real cultivars. Nitrogen concentrations of 5.12, 7.6, 10.12 (control), 12.62 and $15.12 \mathrm{mmol}^{-1}$ in the nutrient solution were studied in a 5x2 factorial randomised experimental design. All runner tips bearing at least one expanded leaf (patent requested) were collected weekly and counted during the growth period. The number of leaves, dry matter (DM) of leaves, crown and root, specific leaf area and leaf area index (LAI) was determined at the final harvest. Increasing $\mathrm{N}$ concentration in the nutrient solution from 5.12 to $15.12 \mathrm{mmol} \mathrm{L}^{-1}$ reduces growth of crown, roots and LAl of strawberry stock plants but did not affect emission and growth of runner tips. It was concluded that for the commercial production of plug plants the optimal nitrogen concentration in the nutrient solution should be $5.12 \mathrm{mmol} \mathrm{L}^{-1}$.
\end{abstract}

Key words: Fragaria x ananassa, hydroponics, propagation, fertigation.

\section{Nitrogênio para crescimento das plantas matrizes e produção de pontas de estolões de morangueiro}

\section{Resumo}

O objetivo do trabalho foi determinar o crescimento e a partição de massa seca entre órgãos de plantas matrizes de morangueiro cultivadas sob cinco concentrações de $(N)$ nitrogênio na solução nutritiva e seu efeito na emissão e no crescimento de pontas de estolões. O experimento foi desenvolvido em ambiente protegido, de setembro de 2010 a março de 2011 , em sistema de cultivo fora do solo com as cultivares Oso Grande e Camino Real. Foram estudadas concentrações de $\mathrm{N}$ de 5,12; 7,6; 10,12 (testemunha); 12,62 e $15.12 \mathrm{mmol} \mathrm{L}^{-1}$ na solução nutritiva em um esquema fatorial 5x2 em delineamento inteiramente casualizado. Todas as pontas de estolões emitidas com pelo menos uma folha expandida (patente requerida) foram semanalmente coletadas e contadas durante todo o período de emissão. O número de folhas, massa seca (MS) de folhas, coroas e raízes e área foliar específica e índice de área foliar (IAF) das plantas matrizes foram determinadas no fim do experimento. O aumento na concentração de $\mathrm{N}$ de 5,12 para 15,12 mmol L-1 reduziu o crescimento da coroa, das raízes e o IAF das plantas matrizes de morangueiro, mas não afetou a emissão e o crescimento das pontas de estolões. Conclui-se que para a produção comercial de pontas de estolões a concentração de N na solução nutritiva pode ser de $5,12 \mathrm{mmol}^{-1}$.

Palavras-chave: Fragaria $x$ ananassa, hidroponia, propagação, fertirrigação.

\section{INTRODUCTION}

In recent years, there has been a trend in the United States and Europe to replace the production of strawberry bare root transplants by plug plants (DURNer et al., 2002; Armeflhor, 2006). Although the restriction for using methil bromide was the origin of this technological change, growers had quickly noticed many advantages to this new type of transplants, such as lower water requirements for crop establishment, higher transplant survival after planting and improved crop yield (TAKEDA and Hokanson, 2003; Hochmuth et al., 2006).

The production of strawberry transplants in Rio Grande do Sul State, Brazil is inexpressive and they need to be imported from the Patagonia region in Argentina (Oliveira et al., 2005). Due to the distance the prices are high and they are often delivered after the ideal moment for planting. Growers search for new production methods capable of supplying high quality transplants to each production region of the country at an adequate moment 
for planting. This goal can be achieved by the "plug plant" production method, as it has been reported in literature (Verdial et al., 2004; Oliveira et al., 2007; Giménez et al., 2008). In such method, stock plants are grown in hydroponical facilities but little attention has been paid to the composition of the nutrient solution used for plant fertigation.

Hydroponical production systems have been patented for producing strawberry plug plants (BisH et al., 2003; Armeflhor, 2006), and several other systems have been described in worldwide literature. Stock plants growing in bags or pots filled with substrate and placed on or above the soil surface were proposed by BisH et al. (2003). In this system, plants were fertigated and the nutritive solution drained to waste, while in the system described by LIETEN (2000) it was collected and reused. In all soilless systems, stock plants have to reach their highest potential number of runner tips, to reduce production costs (Takeda and Hokanson, 2003). The composition of the nutrient solution is one of the main factors affecting plant growth and it has to be adapted to environmental conditions as well as cultivars. It has been reported that for growing strawberry stock plants the composition of the nutrient solution affects the production and quality of runner tips (Bish et al., 2001; Durner et al., 2002).

Nitrogen has been considered the key nutrient in plant growth and yield, affecting photosynthesis and dry matter partitioning (YIN et al., 2003). For the strawberry crop, nitrogen concentrations in the range from $2.16 \mathrm{mmol} \mathrm{L}^{-1}$ to $15.25 \mathrm{mmol} \mathrm{L}^{-1}$ in the nutrient solution have been reported in the literature (Bish et al., 2001; Armeflhor, 2006). In strawberry fruiting plants, high $\mathrm{N}$ concentrations increased vegetative growth and early emission of stolons, reducing fruit yield (Hennion and Vechambre, 1997), but little effects on growth and yield has been reported (CANTLIFFE et al., 2007). In the wild species Fragaria chiloensis, $\mathrm{N}$ increased runner emission and reduced stolon length, but this effect was genotype dependent (Tworkoski et al., 2001). In Santa Maria, RS, Brazil, Oliveira et al. (2010) didn't observe any effect of $\mathrm{N}$ concentration on production of bare root transplants in a growing sand bed. They attributed such result to competition for radiation among plants on the bed and/or for carbon assimilate among plant organs.

The objective of this research was to determine growth and dry matter partitioning among organs of strawberry stock plants under five nitrogen concentrations in the nutrient solution and its effects on emission and growth of runner tips.

\section{MATERIAL AND METHODS}

The experiment was conducted from September 22, 2010 to March 3, 2011, in a polyethylene greenhouse in Santa Maria, Rio Grande do Sul State, Brazil. Average air temperature during the experiment varied between $17.5^{\circ} \mathrm{C}$ (September) and $24.5^{\circ} \mathrm{C}$ (January). A closed soilless system was used (GoDor et al., 2009). The substrate used was sand in $0.21 \mathrm{~m}$ diameter white polyethylene bags. Physical characteristics of the sand were $0.01-0.03 \mathrm{~m}$ gauge, $1.60 \mathrm{~kg} \mathrm{dm}^{-3}$ bulk density and 0.243 $\mathrm{L} \mathrm{dm}^{-3}$ maximum water retention capacity. Bags were placed over fibber cement tiles, at a height of $0.80 \mathrm{~m}$ above the soil. The nutrient solution was supplied daily, six times a day for $15 \mathrm{~min}$ by drip fertigation from a polyethylene reservoir for optimal water and nutrient availability to plants.

The nutrient solution reported by Hennion and VESCHAMBRE (1997) for the strawberry crop was used as control, adjusted to nutrient concentrations of, in $\mathrm{mmol} \mathrm{L}^{-1}: 8.26$ $\mathrm{NO}_{3}^{-}, 1.86 \mathrm{NH}_{4}^{+}, 4.00 \mathrm{H}_{2} \mathrm{PO}_{4}^{-}, 6.00 \mathrm{~K}^{+}, 2.00 \mathrm{Ca}^{+2}, 1.00$ $\mathrm{Mg}^{+2}$ and $1.00 \mathrm{SO}_{4}^{-2}$. Micronutrients quantities were, in $\mathrm{mg}$ $\mathrm{L}^{-1}, 0.03 \mathrm{Mo} ; 0.42 \mathrm{~B} ; 0.06 \mathrm{Cu} ; 0.50 \mathrm{Mn} ; 0.22 \mathrm{Zn}$ and $1.00 \mathrm{Fe}$.

Treatments consisted of five $\mathrm{N}$ concentrations in the nutrient solution: 5.12 (T1), 7.6 (T2), 10.12 (T3 control), 12.62 (T4) and 15.12 (T5) $\mathrm{mmol} \mathrm{L}^{-1}$, at electrical conductivities (EC) of $1.09 ; 1.30 ; 1.60 ; 1.76$ and $2.00 \mathrm{dS} \mathrm{m}^{-1}$, respectively. The $\mathrm{pH}$ was adjusted in the range between 5.5 and 6.5 , by $\mathrm{H}_{3} \mathrm{PO}_{4}^{-}$or $\mathrm{KOH}$ in the concentration of $1 \mathrm{~mol} \mathrm{~L}^{-1}$ whenever necessary. The cultivars Oso Grande and Camino Real were used, in a $5 \times 2$ factorial randomised experimental design and twenty replications of one plant. Separated units of the hydroponical growing system were used for each nutrient concentration. Fertilizers were potassium nitrate, ammonium nitrate, calcium nitrate-Calcinit $^{\circ}$, potassium monophosphate, potassium sulphate and magnesium sulphate. Nitrogen concentrations differed by modifying ammonium nitrate and potassium sulphate quantities in the nutrient solution. Ionic concentrations of $\mathrm{H}_{2} \mathrm{PO}_{4}^{-}, \mathrm{Ca}^{+2}, \mathrm{Mg}^{+2}$ and $\mathrm{K}^{+}$were as the control in all treatments and concentration of $\mathrm{SO}_{4}^{-2}$ was $4 \mathrm{mmol} \mathrm{L}^{-1}$ in $\mathrm{T} 1$.

Micropropagated stock plants of both cultivars were acclimatized and planted in bags on September, 22 ${ }^{\text {nd }}$, 2010. The bags were arranged in four lines at a plant density of 12 plants $\mathrm{m}^{-2}$, with $4.5 \mathrm{dm}^{3}$ of substrate for each plant. The runner emission period was from October, 17,2010 , to March, $3^{\text {rd }}, 2011$, when the experiment was ended. It was recorded on $50 \%$ plants of each treatment. During the experimental period, all runner tips bearing at least one expanded leaf (patent requested) were collected, counted and averaged at fortnightly intervals. Ten runner tips from plants of each treatment were monthly sampled to determine its crown diameter, the number of visible root nodules and dry matter (DM) after drying at $65^{\circ} \mathrm{C}$ until constant mass was reached. At the end of the experiment, six stock plants of each treatment were harvested, the number of leaves counted and DM of leaves, crown and root was determined. Specific leaf area (SLA) was estimated by means of a relationship between DM and $5.02 \times 10^{-5} . \mathrm{m}^{2}$ diameter leaf discs sampled from nine leaves of each plant. Leaf area index (LAI) was estimated from SLA and total leaf DM of plants was determined. Results were submitted to analysis of variance and polynomial regression using the software Sisvar 4.1 (Ferreira, 2000). 


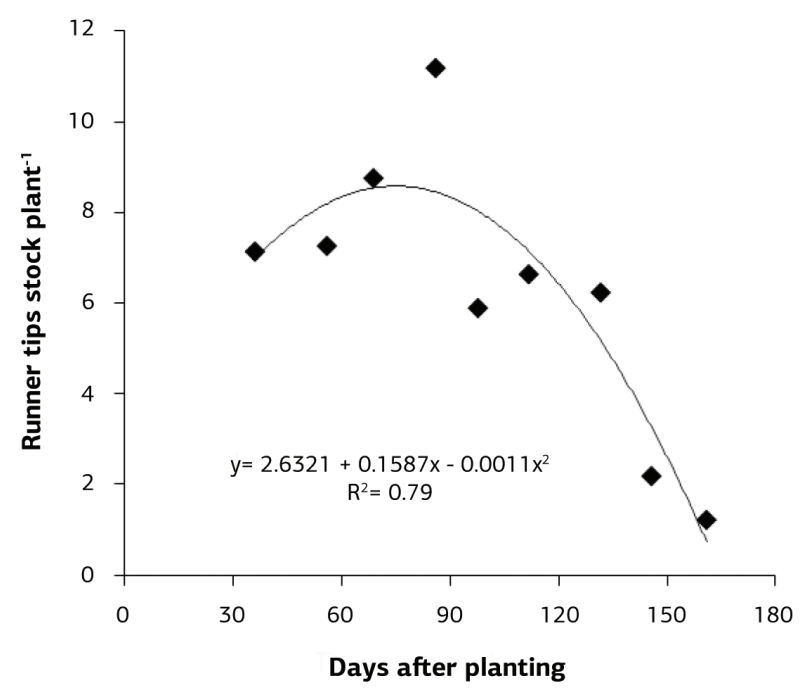

Figure 1. Number of runner tips collected during the experiment from strawberry stock plants grown at $\mathrm{N}$ concentrations of 5.12, 7.60, 10.12 (control), 12.62 and $15.12 \mathrm{mmol} \mathrm{L}^{-1}$ in the nutrient solution. $\mathrm{p}<0.05$.
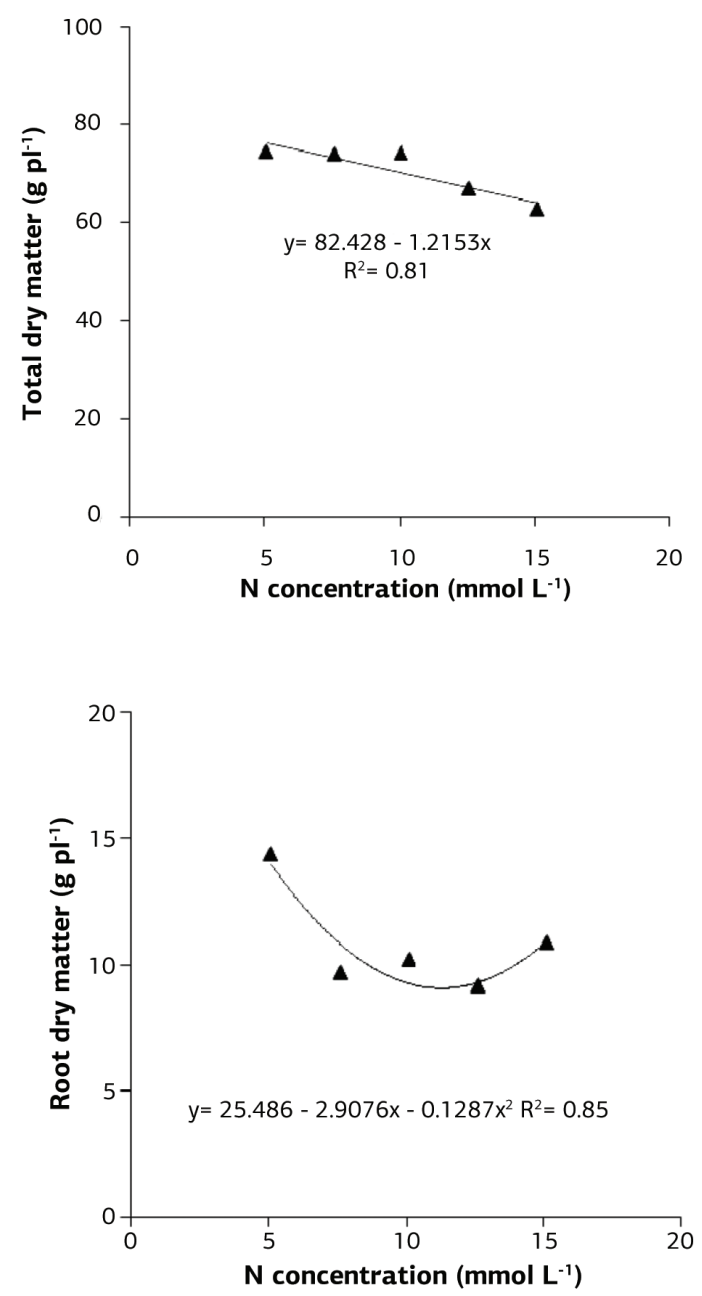

(a)

(c)

\section{RESULTS AND DISCUSSION}

The $\mathrm{N}$ concentration of the nutrient solution did not affect the production of runner tips by stock plants of either cultivars (data not shown) ( $>>0.05)$. The average number was 54 tips per stock plant. The number of runner tips collected during the growing period decreased polinomially (Figure 1). The maximum estimated number was reached from mid-November to mid-December with an average of 17.4 runner tips per stock plant. Crown diameter and DM of runner tips were also not affected and average values were $5.71 \mathrm{~mm}$ and $0.40 \mathrm{~g}$ per runner tip, respectively. Emission and growth of runner tips were similar between cultivars, but average number of root nodules was 5.56 on Camino Real and 2.41 on Oso Grande runner tips.

In stock plants, total and crown DM decreased linearly and were similar between cultivars (Figure 2a,b). Growth of roots decreased in a negative polynomial pattern with highest intensity from $\mathrm{T} 1$ to $\mathrm{T} 2$, without significant differences between cultivars (Figure 2c). Growth of leaves increased linearly in Oso Grande while in Camino Real it increased

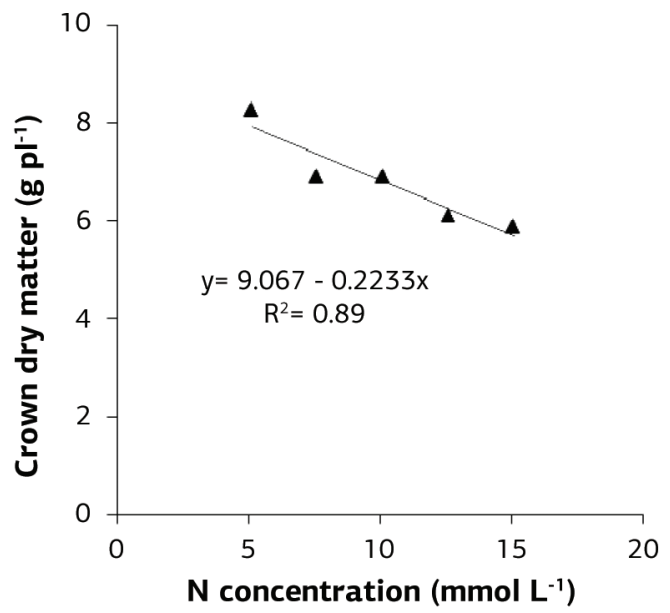

(b)

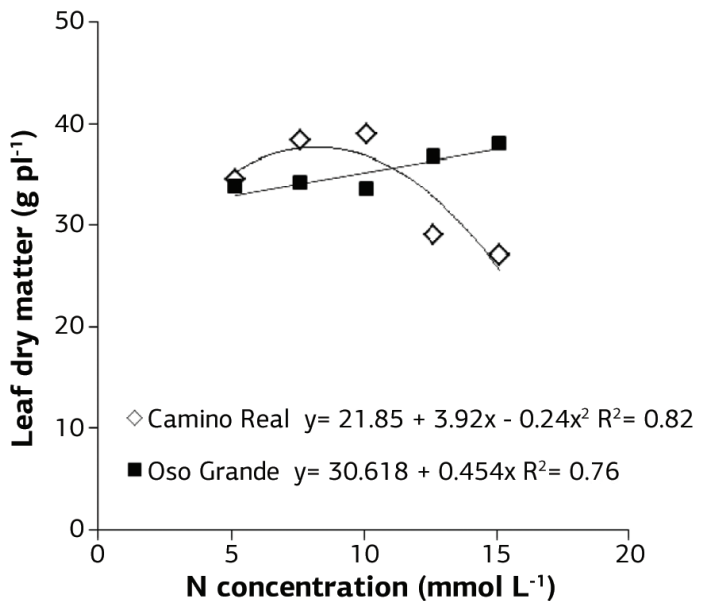

Figure 2. Total (a), crown (b), root (c) and leaf (d) dry matter of strawberry stock plants grown at $\mathrm{N}$ concentrations of 5.12, 7.60, 10.12 (control), 12.62 and $15.12 \mathrm{mmol} \mathrm{L}^{-1}$ in the nutrient solution. $\mathrm{p}<0.05$. 
until $8.2 \mathrm{mmol} \mathrm{L}^{-1} \mathrm{~N}$ in the nutrient solution (Figure $2 \mathrm{~d}$ ). Number of leaves increased in Oso Grande from T1 to T2, decreasing thereafter (Figure 3a), and LAI decreased polinomially in both cultivars (Figure $3 \mathrm{~b}$ ).

The lack of $\mathrm{N}$ effect on emission and growth of strawberry runner tips was surprising. In Fragaria chiloensis, Tworkoski et al. (2001) reported an increasing number of stolons on plants grown in nutrient solutions with $\mathrm{N}$ concentrations from zero up to $5.7 \mathrm{mmol} \mathrm{L}^{-1}$. In a similar study using Fragaria chiloensis, ALPERT (1991) reported a $20 \%$ increase in stolon growth by effect of $\mathrm{N}$ doses from 0 to $3.6 \mathrm{mmol} \mathrm{L}^{-1}$. Nevertheless, the range of $\mathrm{N}$ concentrations used by both authors was lower than those of the present experiment. At low $\mathrm{N}$ availability plant growth and developmental processes might be affected by isometric and allometric relationships. Strawberry plant development has been considered to be triggered manly by air temperatures between $20-26{ }^{\circ} \mathrm{C}$ and photoperiod ranging from 13-14 hours (Sonsteby, 1997). However, in spite of environmental variables, a new developmental phase can take place only when minimum growth has been reached by the plant at the previous phase, to assure its isometry (McConnaughay and Coleman, 1999). In this way, it could be interpreted that $\mathrm{N}$ concentrations used by Tworkoski et al. (2001) and Alpert (1991) were low enough to isometrically reduce plant growth and, as a consequence, runner emission. This suggests that the lowest $\mathrm{N}$ concentration of $5.12 \mathrm{mmol} \mathrm{L}^{-1}$ used in the present experiment was not limiting to the growth and development of strawberry plants.

The crop management practices for plant and stolon growth can affect production and crown diameter of runner tips. In this study, only first order runner tips bearing one expanded leaf were collected and its crown diameter was higher than that reported by Oliveira et al. (2010) and Giménez et al. (2008). These authors used a growing sand bed for simultaneously producing bare root transplants on the bed surface and runner tips on suspended stolons growing downward between beds. Present results agree with Durner et al. (2002), to whom runner tips collected in weekly intervals are bigger and lead to more uniform transplants. According Oliveira et al. (2010) , no difference was found in emission of runner tips at $\mathrm{N}$ concentrations from 8 to $17 \mathrm{mmol} \mathrm{L}^{-1}$ and it was attributed to competition for assimilates between plant and runner tip growth, as final plant density by mother and daughter plants on the bed surface reached 339 plants $\mathrm{m}^{-2}$. In the present experiment, plant density was of 12 plants $\mathrm{m}^{-2}$ and stolons were not kept to grow, as a way to reduce such competition. Nevertheless, production and crown diameter of runner tips were also not affected and the assimilate limiting hypothesis was not confirmed. Probably, temperature and photoperiod are the key environmental variables controlling the propagation of the strawberry plant, as suggested by SonsteBy (1997), and the $\mathrm{N}$ concentration of $5.12 \mathrm{mmol} \mathrm{L}^{-1}$ is not limiting for runner tip production.

In the Southern Brazil, strawberry growers replant their crops mainly in April and May. To be used in this period plug plants have to be collected at least 30 days before. The maximum production of runner tips is from mid-November to mid-December and decreases strongly thereafter (Figure 1). This time period is too early for commercial plug plant production, being a handicap for this production method. Cultural practices had to be searched to overcome it. Transplants of horticultural crops have

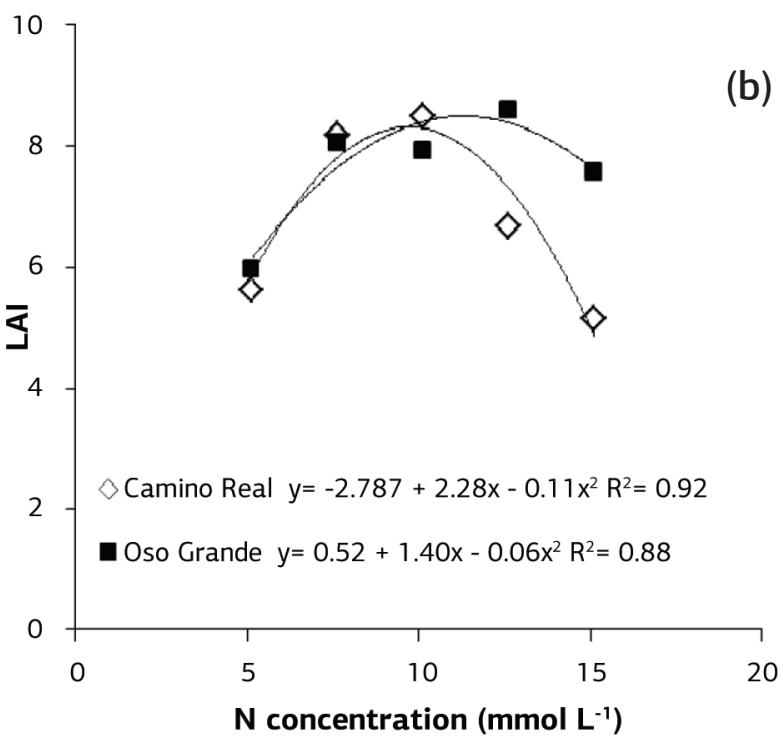

Figure 3. Number of leaves (a) and leaf area index (LAI) (b) of strawberry stock plants grown at N concentrations of 5.12, 7.60, 10.12 (control), 12.62 and $15.12 \mathrm{mmol} \mathrm{L}^{-1}$ in the nutrient solution. $\mathrm{p}<0.05$. 
been produced mainly in 128 cell-polystyrene trays for economical reasons. For strawberry plug plants produced in November-December, trays with bigger cells might be used without increase in production costs. Another possibility might be the cold storage of runner tips for further rooting and plug plant production, as suggested by HokAnson et al. (2004). More research is needed to test such hypothesis.

Present results have implications for the commercial production of strawberry runner tips. The $\mathrm{N}$ concentration of the nutrient solution can be reduced to about 5 mmol L ${ }^{-1}$ with environmental and economical benefits. Management practices may also be reviewed. The fact that DM and crown diameter of runner tips were not affected by either $\mathrm{N}$ availability and growth of the stock plant suggests that runner tips are able to produce the carbon assimilates needed for growth. If they were dependent on water and nutrients from the stock plant, it was only at initial developmental stages, before root emission. Thus, shoot growth of stock plants might be reduced and controlled by cultural practices like pruning, defoliation or increasing plant density. Benefits would be less consumption of nutrient solution and higher surface use efficiency of growing beds.

\section{CONCLUSION}

Increasing the $\mathrm{N}$ concentration of the nutrient solution from 5.12 to $15.12 \mathrm{mmol} \mathrm{L}^{-1}$ reduces growth of crown, roots and LAI of strawberry stock plants but does not affect emission and growth of runner tips for Oso Grande and Camino Real cultivars. It was concluded that for the commercial production of plug plants the optimal nitrogen concentration in the nutrient solution should be $5.12 \mathrm{mmol} \mathrm{L}^{-1}$.

\section{ACKNOWLEDGMENTS}

To the Conselho Nacional de Desenvolvimento Científico e Tecnológico for financial support, grants 300998/2009-0 and 470255/2009-0 and to Coordenação de Aperfeiçoamento de Pessoal de Nível Superior for the fellowship.

\section{REFERENCES}

ALPERT, P. Nitrogen sharing among ramets increases clonal growth in Fragaria chiloensis. Ecology, v.72, p.69-80, 1991.

ARMEFLHOR. Rapport technique sur la production de plants Fraisimotte $^{\oplus}$ a l'ile de la reunion. Saint-Pierre: Association
Réunionnaise pour la modernization de l'Economie fruitière légumière et hortícola, 2006. 69p.

BISH, E.B.; CANTLIFFE, D.J.; CHANDLER, C.K. A system for producing large quantities of greenhouse grown strawberry plantlets for plug production. HortTechnology, v.11, p.636-638, 2001.

BISH, E.B.; CANTLIFFE, D.J.; CHANDLER, C.K. Strawberry plug transplant system. United States Patent. Patent number: US 006598339 B1. 2003.

CANTLIFFE, D.J.; CASTELlanOS, J.V.; PARANJPE; A.V. Yield and quality of greenhouse-grown strawberries as affected by nitrogen level in coco coir and pine bark media. Florida State Horticultural Society, v.120, p.157-161, 2007.

DURNER, E.F.; POLING, E.B.; MAAS, J.L. Recent advances in strawberry plug transplant technology. Hort Technology, v.12, p.545-550, 2002.

FERREIRA, D. F. Sistema de análise estatística para dados balanceados - SISVAR 4.1. Lavras: UFLA, 2000. 141p.

GIMÉNEZ, G.; ANDRIOLO, J.L.; JANISCH, D.I.; GODOI, R.S. Closed soilless growing system for producing strawberry bare root transplants and runner tips. Pesquisa Agropecuária Brasileira, v.43, p.1757-1761, 2008.

GODOI, R.S.; ANDRIOLO, J.L.; FRANQUEZ, G.G; JANISCH, D.I.; CARDOSO, F.L.; VAZ, M.A.B. Produção e qualidade do morangueiro em sistemas fechados de cultivo sem solo com emprego de substratos. Ciência Rural, v.39, p.1039-1044, 2009.

HENNION, B.; VESCHAMBRE, D. La fraise: maîtrise de la production. Paris: CTIFL, 1997. 299p.

HOCHMUTH, G.; CANTLIFFE, D.; CHANDLER, C.; STANLEY, C.; BISH, E.; WALDO, E.; LEGARD, D.; DUVAL, J. Containerized strawberry transplants reduce establishment-period water use and enhance early growth and flowering compared with bare-root plants. HortTechnology, v.16, p.46-54, 2006.

HOKANSON, S.C.; TAKEDA, F.; ENNS, J.M.; BLACK, B.L. Influence of plant storange duration on strawberry runner tip viability and field performace. HortScience, v.39, p.1596-1600, 2004.

LIETEN, F. Recent advances in strawberry plug transplants technology. Acta Horticulturae, n.513, p.383-388, 2000.

McCONNAUGHAY, K.D.M.; COLEMAN, J.S. Biomass allocation in plants: ontogeny or optimality? A test along three resource gradients. Ecology, v.80, p.2581-2593, 1999.

OLIVEIRA, R.P.; NINO, A.F.P.; SCIVITTARO, W.B. Mudas certificadas de morangueiro: maior produçáo e melhor qualidade da fruta. A Lavoura, v.108, n.655, p. 35-38, 2005.

OLIVEIRA, R.P.; BRAHM, R.U.; SCIVITTARO, W.B. Produção de mudas de morangueiro em casa de vegetação utilizando recipientes suspensos. Horticultura Brasileira, v.25, p.107-109, 2007. 
OLIVEIRA, C.S.; COCCO, C.; ANDRIOLO, J.L.; ERPEN, L.; FRANQUEZ, G.G. Produção e qualidade de propágulos de morangueiro em diferentes concentraçóes de nitrogênio no cultivo sem solo. Revista Ceres, v.57, p.554-559, 2010.

SONSTEBY, A. Short-day period and temperature interactions on growth and flowering of strawberry. Acta Horticulturae, n.439, p.609-616, 1997.

TAKEDA, F.; HOKANSON S.C. Strawberry fruit and plug plant production in the greenhouse. Acta Horticulturae, n.626, p.283$285,2003$.
TWORKOSKI, T.J.; BENASSI, T.E.; TAKEDA, F. The effect of nitrogen on stolon and ramet growth in four genotypes of Fragaria chiloensis L. Scientia Horticulturae, v.88, p.97-106, 2001.

VERDIAL, M.F.; NETO, J.T.; ORTIGOZA, L.E.R. Produção de mudas de cultivares de morangueiro em duas épocas de coleta. Horticultura Brasileira, v.21, p.231-233, 2004.

YIN, X.; LANTINGA, E.A.; SCHAPENDONK, H.C.M.; ZHONG, X. Some quantitative relationships between Leaf Area Index and canopy Nitrogen ontent and distribution. Annals of Botany, v.91, p. 893-903, 2003. 